\title{
食中毒事例より分離した腸炎ビブリオの
}

\section{新しいK 抗原型について}

\begin{tabular}{|c|c|c|}
\hline 梧 & 木下 & 喜雄 \\
\hline 信治 & 竹田 & 美文 \\
\hline
\end{tabular}

\author{
大阪府立公衆衛生研究所 \\ 大阪市東成区中道 1 丁目3-69 $\overline{\mathbf{T}} 537$ \\ $*$ 大阪大学微生物病研究所 \\ 大阪府吹田市山田上 $\mathbf{T} 565$ \\ 〔受付：1月 5 日，1979年〕
}

昭和53年 4 月から10月末までに，大阪府下で発生した 腸炎ビブリオ食中毒20例中13例から，O群がO4 亿群別 されながら，K型別不能の神奈川現象陽性株を 47 株分離 した。これら分離株の $\mathrm{K}$ 抗原型を調べた結果, 從来報告 されているK1〜 K62 とは異なる新しいK抗原型である ことがわかつたので報告する。

分離侏の生化学的性状を常法汇従つて調べた結果, す べて腸炎ビブリオの性状に一致した。分離株のらち 1 株 (Vibrio parahaemolyticus OP-217) を選び，実験に用い た。O群別には，市肘 (東芝化学) の腸炎ビブリオ(O 群別) 診断用血清 $(\mathrm{O} 1 \sim \mathrm{O} 11)$ と $V$. parahaemolyticus a-11) および OP-2042) に対する自家製の抗血清 (O12) を用いた。K抗原型別には, 市販 (東芝化学) の腸炎ビ ブリオ( $\mathrm{K}$ 型別) 診断用血清 $(\mathrm{K} 1 \sim \mathrm{K} 60)$ と, 岐皁県衛生 研究所より分与を受けた $V$. parahaemolyticus KY.75V-8(O5: K61 $)^{3)}$ およよ゙ K.No. $22(\mathrm{O} 8: \mathrm{K} 62)^{4)}$ の自家

表 1. 抗 OP-217 血清と K17 抗原の交差スラィ ド凝集反応

\begin{tabular}{|c|c|c|c|c|c|c|}
\hline \multirow{2}{*}{$\mathrm{K}$ 抗 原 } & \multicolumn{3}{|c|}{ 抗 $\mathrm{K} 17$ 血清 ${ }^{a}$} & \multicolumn{3}{|c|}{ 抗 OP-217 血清 } \\
\hline & $\times 1^{b}$ & $\times 20$ & $\times 50$ & $\times 1$ & $\times 20$ & $\times 50$ \\
\hline $\mathrm{K} 17$ & $\mathrm{H}^{c}$ & 世 & H & + & + & - \\
\hline OP-217 & - & - & - & H & 世 & 曲 \\
\hline
\end{tabular}

$a$ 抗K17血清はK17パイロット株に対する自家製抗 血清を用いた。

b 抗血清の稀釈倍数。

‘ スライド凝集反応の成績を凝集の強さによつて+, \#, 卅の 3 段階に分けて判定した。一は凝集陰性 を示す。
製抗血清を用いた。また，表 1 抢よび表 2 に示すように， 抗 OP.217 未吸収血清がきわめて軽度ではあるが，K17 パイロット株（O5：K17，RIMD 2210127 株）と凝集反 応を示したので，K17パイロット株の自家製抗血清を作 製して新K抗原との異同性を検郡した。

V. parahaemolyticus OP-217 は, スライド凝集反応 の結果, 市販の K $1 \sim \mathrm{K} 60$ 抗血清拈上び自家製の K 61 抗 血清とK62抗血清に対して，すべて疑集しなかつた。

OP-217 株の抗K血清を，ウサギを用いて常法通り作 製し，K1〜K60 パイロット株，KY.75-V-8 株(K61) および K-No. 22株 (K62) との間のスライド疑集反応を 行つたところ, 抗 OP -217 血清は, OP-217 株を強く凝 集すると同時に，K17パイロット株を弱く凝集した。抗 OP-217 血清, および K 17 パイロット株を用いて作製し

表 2. 抗 OP-217 血清の吸収血清の特異性

\begin{tabular}{|c|c|c|c|}
\hline \multirow{3}{*}{ 抗 } & \multicolumn{3}{|c|}{ 抗 OP-217 血清 } \\
\hline & \multirow{2}{*}{$\begin{array}{l}\text { 末 吸収 } \\
\text { 血 清 }\end{array}$} & \multicolumn{2}{|c|}{ 吸収に用いた抗原 } \\
\hline & & OP-217 & $\mathrm{K} 17$ \\
\hline OP -217 & $1280^{a}$ & $-b$ & 640 \\
\hline K 17 & 160 & - & 一 \\
\hline $\begin{array}{l}\mathrm{K} 1 \sim \mathrm{K} 16 \\
\mathrm{~K} 18 \sim \mathrm{K} 60\end{array}$ & - & 一 & - \\
\hline $\begin{array}{c}\mathrm{KY}-75-\mathrm{V}-8 \\
(\mathrm{~K} 61)\end{array}$ & - & - & - \\
\hline $\begin{array}{c}\mathrm{K} \cdot \mathrm{No} .22 \\
(\mathrm{~K} 62)\end{array}$ & - & - & - \\
\hline
\end{tabular}

$a$ 試験管内凝集反応によつて調べた凝集素価。凝集 を起こす血清の最高稀釈倍数で表わした。

b 血清40倍以上の稀釈で凝集陰性。 
た自家製抗血清を，それぞれ稀釈して，K 17 株と OP 217 株に対するスライド疑集反応を行つた成績を表 1 に 示す。自家製抗K 17 血清は，50倍稀釈でもK 17 パイロッ 卜株を強く凝集したが，OP-217 株は原血清を用いても 凝集しなかつた。一方抗 OP.217血清は，20倍稀釈まで は，K17パイロット株を弱く凝集した。しかし，OP-217 株との間の凝集反応は，50倍稀釈でも強陽性であつた。

以上の成績から，OP - 217 株は，K17抗原を少量含ん でいるが，新しいK抗原を主抗原としていることが考え られた。

抗 OP - 217 血清をK 17 パイロット株で吸収して得た吸 収血清の特異性を, 試験管内凝集反応で調べた結果を表 2 亿示す。抗 OP-217血清は, K17パイロット株で吸収 すると, 凝集素価が若干低下する傾向があつたが, 吸収 血清は，OP-217 株のみに対して特異的な凝集を示し， K17パイロット株を含む K1～K62 の菌株とは凝集しな かつた。したがつて OP-217 株は，K1〜 K62 以外の新 しいK抗原を主抗原とする菌株であると結論した。なお 自家製の抗 K17血清（凝集素価：2560）を，OP-217 株で 吸収して得た抗血清の K 17 パイロット株に対する凝集素
価は，未吸収血清とまつたく変わらなかつた。

抗 OP.217血清の吸収血清を用いて, 分離株すべての K抗原型を調べた結果，すべてが抗 OP-217血清と凝集 した。

今回の分離株 47 株の代表株を V. parahaemolyticus OP-217 とし, その血清型を $\mathrm{O} 4: \mathrm{K} 63$ とするよう提案 する。

本論文の要旨は, 第 12 回腸炎ビブリオシンポジウム (岡山市)において発表した。

\section{文献}

1）石橋正憲, 木下喜雄, 山本博之, 光田文吉, 国田 信治, 本田武司, 竹田美文, 三輪谷俊夫 (1977)： 日細菌誌, 32, 447-484.

2）石橋正憲，木下喜雄，宮野啓一，新原富夫，国田 信治, 竹田美文, 三輪谷俊夫 (1979) : 日細菌誌, 34, 395-401.

3）横田陽子, 所光男, 西山員喜, 寺田友次 (1977)： 日細菌誌，32，509-510.

4) 岡崎秀信, 寺田友次 (1978) : 日細菌誌, 33, 421422 . 